\title{
Personal and interpersonal factors with the inclination to relapse
}

\section{Faktor personal dan interpersonal yang mempengaruhi kecenderungan kambuh bagi mantan pengguna obat-obatan}

\author{
Asbah Razali \\ University of Malaya \\ Jalan Universiti, 50603 Kuala Lumpur, Wilayah Persekutuan Kuala Lumpur, Malaysia. \\ Phone: +60 3-7967 7022 \\ E-mail: asbahrazali@um.edu.my
}

\begin{abstract}
This study aims to identify a relationship between the personal factor of coping; the interpersonal factors of familial, friend, and societal support and the inclination to relapse. This study involves the participation of 169 former addicts that completed their treatment and rehabilitation period, by utilising four instruments: the Inventory of Drug-Taking Situations, (IDTS) by Annis and Martin (1985); Coping Strategy Inventory (COPE) by Carver and the Social Provisions Scale (SPS) by Russell and Cutrona (1984). The findings shows the inclination to relapse among former addicts are at a high level for the eight dimensions of the inclination to relapse. This means the participants of this study are at a high risk of relapsing into drug use. The descriptive analytical results towards the problem-focused coping, the emotional coping and evasive coping variables show it at a low level. This also applies to the analysis for the family, friend, and societal support variables. In addition, the correlation analysis for the variables of problem-focused, emotional, and evasive coping, selfefficacy, and family, friend, and societal support, shows a negative significant relationship with the inclination to relapse, with the relationship strength between $r=-.60$ and $r=-.80$. Therefore this study shows the importance of the personal and interpersonal factors in reducing the problem of inclination to relapse among former addicts that completed their treatment and rehabilitation period. In conclusion, results show the importance of the personal and interpersonal factor in the problem of inclination to relapse.
\end{abstract}

Keywords: drug abuse, family support, friend and societal support, coping strategies, relapse

\begin{abstract}
Abstrak
Penelitian ini bertujuan untuk mengidentifikasi faktor personal dalam menanggulangi penggunaan obatobatan terlarang; faktor interpersonal seperti keluarga, teman, dan dukungan masyarakat dan hubungannya dengan kecenderungan bagi mantan pengguna obat-obatan terlarang untuk kembali menggunakan obatobatan. Penelitian ini melibatkan partisipasi dari 169 mantan pecandu obat-obatan terlarang yang sudah menyelesaikan masa perawatan dan rehabilitasi, dengan menggunakan 4 instrumen: the Inventory of DrugTaking Situations, (IDTS) oleh Annis \& Martin (1985); Coping Strategy Inventory (COPE) oleh Carver and the Social Provisions Scale (SPS) oleh Russell \& Cutrona (1984). Hasil dari penelitian ini menunjukkan bahwa berdasarkan delapan dimensi kecenderungan, kemungkinan kambuh bagi mantan pengguna obat terlarang berada di level tinggi. Dengan kata lain, partisipan dalam studi ini memiliki risiko tinggi untuk kembali menggunakan obat-obatan terlarang. Hasil analisa deskriptif terhadap upaya penanggulangan yang berorientasi pada masalah, upaya penanggulangan berorientasi pada emosi, serta upaya para mantan pengguna untuk menghindari obat-obatan terindikasi dalam level rendah. Hasil yang sama juga berlaku pada analisis variabel keluarga, teman, dan dukungan masyarakat. Lebih lanjut, analisis korelasi pada variabel yang berfokus pada permasalahan, emosi, upaya penanggulangan dengan penghindaran, persepsi diri sendiri, dan teman, keluarga, dan dukungan sosial menunjukkan hubungan negatif terhadap kecenderungan kambuh bagi mantan pengguna obat-obatan, dengan kekuatan hubungan antara $r=-.60$ dan $r=-.80$. Penelitian ini menunjukkan pentingnya faktor personal dan interpersonal dalam mengurangi kecenderungan kambuh bagi mantan pengguna obat-obatan terlarang yang sudah menyelesaikan masa perawatan dan rehabilitasinya.
\end{abstract}

Kata-kata kunci: penyalahgunaan obat, dukungan keluarga, dukungan teman dan keluarga, strategi penanggulangan, kambuh 


\section{Introduction}

The increase in the number of drug addicts by year is alarming to many. This problem would not only ruin the human capital, the hope of the nation, but would also cause the government to bear a burdensome amount to pay for the cost of treatment and recovery. If these addicts are not rehabilitated, Malaysia would suffer heavy losses, socially and economically. However, efforts to rehabilitate former drug addicts are not easy, as the problem of relapse is a cyclical phenomenon. As mentioned previously, a number of factors have been identified to explain the issue of inclination to relapse among former addicts, including the personal, interpersonal, and contextual factors.

The personal factor includes the coping and self-efficacy factors. Folkman \& Lazarus (1984) defines coping as an individual effort to control the situation beyond his level of adjustment. Coping basically is an action-oriented and intra-psychic effort to overcome, resist, reduce, and minimise pressure or internal and environmental conflict. It is able to provide positive effects to the individual such as reducing anxiety and psychosomatic symptoms as well as increase one's satisfaction with life. Coping is also any strategy or effort carried out as a response to stress-causing events one faces (Compas 1987).

In addition, personal factors also cover the self-efficacy factor (Minervini, Palandri, Bianch, Bastiani \& Paffi 2011; Ramo \& Brown 2008; Macleod, Hickman, \& Smith 2005). Self-efficacy is seen as a form of response when an individual faces a problematic situation and their capacity to produce the necessary behaviour to achieve their level of self-performance. According to Marlatt and Gordon (1985), the inclination to relapse is not only caused by exposure to high-risk situations, but also by the perception and ability of the addict to face said situation could also be used as a forecast to the inclination to relapse.

However, the personal factor is not the only one linked to the inclination to relapse. Other factors have also been considered as contributing to this problem, including the ecological context factor such as social support provided by family, friends, and members of society. Most previous studies found the lack of social support increase the inclination to relapse (Martino, Ellickson, \& McCaffrey 2009). This has also been acknowledged by Moon, Jackson, \& Hecht (2000) in their study that found social support, especially by family members, is also linked to the success rate of former addicts to overcome their desire for drugs.

Brooks \& Rice (2007) in their study found that families that did not provide support during the recovery process of former addicts become a risk factor that increases the rate of inclination to relapse. This is because family is a context that has significant effect on the positive development of an individual and could influence one's behaviour. Simons, Christine, Rand, \& Glen, (1998) in his study found that a lack of familial support causes former drug addicts to feel isolated, rejected, and thus contributes to their inclination to relapse.

Furthermore, friend support is also said to contribute to the inclination to relapse (Chen, Sheth, Elliott, \& Yeager 2004; Kandel \& Yamaguchi). This has been acknowledged by Macleod et al. (2005). that states that throughout the period of adolescence, the individual spends more time with their environment, especially with friends and less time with family, thus friends have a stronger influence on the individual as opposed to the family. Friends are said to influence behaviour and is a source of rationalisation for various types of deviant behaviours (Conger \& Rueter 1996). Therefore, friends could be identified as an important factor enabling the inclination to relapse among former drug addicts.

Societal support has also been identified as one factor that leads to the increase in risk of inclination to relapse. This is the main problem for former addicts, if they feel unaccepted by society and their surroundings. According to Luoma, Twohig, Waltz, Hayes, Roget, Padilla, \& Fisher (2007) the negative stigma that society inflicts on former addicts have an effect on their self-confidence 
to change, thus, most former addicts use the stigma excuse as a justification for their decision to reuse (Room 2005). What is the demographic profile of a former drug addict? The specific objective of this study is as such: deciding whether there is a link between the personal factor (coping and self-efficacy), the interpersonal factor (familial, friend, and societal supports), contextual factor (the treatment end period and history of drug use in the family) and the inclination to relapse among former drug addicts.

According to Compas (1987), coping is any strategy or effort carried out as a response to stress events. It could shape one behaviour or thought. It could provide positive effects to the individual such as reducing anxiety and increase self-satisfaction. Accordingly, Frydenberg (2002) and Kiser \& Black (2005) in their studies related to drug addicts found they require coping to evade the risk of increase in the inclination to relapse.

Breese (2005) in his study acknowledges the lack of skills in facing stress such as alcohol intake and drug abuse affects the addict's ability to face problems. This situation also affects their health and reduces their internal values. Therefore, they require proper planning to ensure their readiness to face any pressure and endure life's hardships.

Previous researchers (such as Verdejo 2007; Sinha 2001; Dodge, Sindelar \& Sinha 2005; Klingemann 1994; McIntosh \& McKeganey 2000) report that the risk of inclination to relapse is higher among drug addicts due to a lack of an effective problem-coping strategy for when they encounter high-risk pressure and situations. According to Flynn, Joe, Broome, Simpson and Brown (2003) and Scott \& Dennis (2005) addicts realise their actions contradict societal norms, but they are willing to do anything to fulfil their desires without care for the effects and outcome of their actions.

This view is in line with the statement by Cornelius, Maisto, \& Pollock (2003) that the lack of selfcontrol by addicts lead to their aggressive behaviour, beyond control and expectations. Meanwhile, McIntosh and McKeganey (2000) and Stimson \& Oppenheimer (1982) in their studies found that the addiction to drugs transforms the addict's self-awareness and causes a decline in their self-control. This is because the drug overtakes their internal coping capability. In fact, those with problems look to other sources to depend on, such as support from family, siblings, friends, or others they think could help them overcome their problems (Muuss 1996; Seiffge-Krenke 2000). Nevertheless, when these required supports are unattainable, they begin to act beyond expectation when faced with pressure.

Marlatt \& Gordon (1985) states self-efficacy refers to a complex cognitive process that includes expectation, evaluation, resolution, and the physiological effects in someone when faced with a problematic situation. Meanwhile, Maddux \& Gosselin (2001) states self-efficacy consists of two aspects: trust in the self's capability to overcome risky situations, and trust in their expectations. Self-efficacy could influence one in taking action to accomplish their expected goals. Self-efficacy acts as a deterrent to negative behaviour as it covers cognitive control and expectation of behaviour.

A systematic and overall study on relapse behaviour has been carried out by Marlatt \& Gordon in 1985. Results show about $35 \%-58 \%$ of drug addicts would relapse two weeks after the end of the treatment period. Results found that addicts who relapse during this period are in a stressful situation and do not have adequate skills to control their environmental pressure. This is because they have two choices, either to continue with their addiction or resist the temptation to reuse. The capability to overcome stress is based on the self-efficacy internal strength. This study implies that addicts should prepare themselves with the ability for self-control when facing stress to avoid relapsing into drug use.

There is a study by Haegerich \& Tolan, (2009) related to the self-efficacy factor and social support towards former addicts that have ended their 30 day, 60 day, 90 day, and 120 day treatments. Results show a significant link between the individual factor and drug reuse for the 30-day treatment. On the 
$30^{\text {th }}$ day, there is a significant difference in the mean score between addicts with high self-efficacy and those with low self-efficacy. Results also found that among the reasons related to relapse within the 30-day period were the addicts not prepared to change, lack of motivation, and lack of support. For the addicts that relapse within the 60-day to 120-day period, the lack of social support drove them back to addiction.

Results also found a significant relationship between self-efficacy and period of relapse, whereby the addicts that succeed in maintaining the period of relapse is seen with a higher self-efficacy score. Regressive analysis shows the higher the self-efficacy level post-treatment, the higher the possibility of addicts controlling themselves from relapsing for a longer time. The studies related to self-efficacy has not only been done on drug addicts. Gulliver, Hughes, Soloman, \& Dey (1995) studies selfefficacy and addiction behaviour by focusing on heavy smokers. This study is done on 630 smokers prepared to stop smoking immediately through the interview method. All respondents were found to have stopped smoking within a periodof twoto tn days after the interview was conducted. Smokers with high self-efficacy levels could control their smoking behaviour within 30 days after the interview.

This finding is seen to be in line with Macleod et al. (2005). who also carried out a study on 146 smokers. The study was done in six two-hour sessions a week. The respondents were required to provide a probability on a percentage scale of $10 \%$ to $100 \%$ that they could resist the urge to smoke based on 50 questionnaire items. The score of each item was obtained by taking an item average of the answers given. Evaluation of self-efficacy was taken in one, two, three, and six months after treatment ended. Results show after receiving treatment, evaluation on the capability to resist smoking behaviour is controlled, but self-efficacy was not a significant predictive factor. However, results also found the self-efficacy measured during and after treatment could predict the rate of smoking but self-efficacy could not predict whether or not a smoker could maintain not smoking.

In fact, if they consider drugs as having a negative effect, they would do their utmost to resist and control themselves from relapsing. This is acknowledged by Greenfield et al. (2009) who found that self-efficacy influences someone to take any action to reach their goals. The individual is inclined to choose to take part in activities that they feel confident in and able to do, and avoid doing activities they feel is undoable. This is because self-efficacy influences one's expectations to decide their response.

Previous researchers such as Dimeff \& Marlatt (1998) in their study concluded that family support offers the opportunity for addicts to learn the lifestyle of normal individuals to prevent them from relapsing. This is acknowledged by other researchers (such Hall, Wasserman \& Havasay 1991; Brook, Whiteman, Gordon \& Cohen 1986) in their studies that also discovered one factor that contributes to inclination to relapse is a lack of acceptance from family members. They stress that the family members should be responsible in helping former addicts live a drug-free life.

In line with this view, previous researchers (such as Bezuidenhout \& Joubert 2003; Focus Adolescent Service 2008; Goodwin 2000; and Van Der Westhuizen 2007) often report that support provided by families could curb the inclination to relapse. Family support allows addicts to go through a positive change in the rehabilitation process and shape self-confidence. This is because former addicts require acceptance and support from individual close to them. If the family fails to provide this support, the addicts would then turn to other supports that could fulfil their needs. In fact, according to Nevide, Rathus, \& Greene (2011), family members could play an effective role as a support group.

In addition, Perdani (2012) also carried out a study on family member acceptance of former addicts and found that it is usually the mother that seeks out a solution through various means, such as consulting a doctor, lawyer, or psychologist to provide support for the addicted family member. This situation shows the mother would try their best to protect and secure their family members involved in drugs. However, usually the addicts would then reject family effort and advice, and would relapse. 
Mahmood Nazar et al. (1997) in their study emphasised on family support in building a positive and effective relationship for the former addict. Their study not only focuses on the former addict's relationship with the family, but also includes personal development, career, social activity, and a healthy lifestyle. Results found that family support is important in the recovery process and relapse prevention. This shows that family support is necessary in maintaining treatment and recovery for the addicts. Therefore, it should be emphasised here that family support is required to ensure the success of treatment and prevent the inclination to relapse (Daley 2011).

On the issue of family support and inclination to relapse in Malaysia, a number of researchers have looked into this element. Among them was the study carried out by Taib \& Khairi (2000), who examines the relationship between family communication among the families of addicts and families of non-addicts. Results show that weak and ineffective communication in the families of former addicts is one possible factor that could cause addicts to relapse.

This is because familial support is necessary to ensure to success of the recovery process and the family's indifferent attitude and ostracising of former addicts would thwart the recovery process and causes addicts to relapse. Family support could prevent former addicts from returning to their old habits. In conclusion, high moral and emotional support could indirectly increase the self-confidence of addicts and decrease the risk of inclination to relapse.

Yahya \&Mahmood (2002) in their study also agree that family support is the main factor identified in contributing to the inclination to relapse. Findings show a lack of open interaction between former addicts and their family members increase the inclination to relapse among the addicts. Results show that almost $57 \%$ of the respondents admit difficulty in sharing their problems with the family. If this persist, they would face a difficult situation and would then lead to the inclination to relapse.

A study by Fauziah \& Naresh (2009) on 400 former addicts from eight drug rehabilitation centres throughout Peninsular Malaysia also found family support to be one of the factors influencing the inclination to relapse among former addicts. The study also found that lack of familial and societal support encourages former addicts to pick up the old habit after treatment has ended.

According to Macleod et al. (2005). during adolescence individuals spend more time with their environment, especially with their friends and spend less time with their family, thus friends have a stronger influence on them. This is because friends are part of the social environment that could influence behaviour, and friends could be a source of rationalisation for deviant behaviours (Akers 1998; Conger \& Simons 1997). In his regard, friends are found to influence former addicts in their decision to relapse (Gouws et al. 2000). Therefore, friends have been identified as an important factor enabling the inclination to relapse among former addicts (Kandel 1996).

In addition, friends are also a source of reference of values and norms in the child's self-development (Gouws, Kruger, \& Burger 2000). The young, especially, require acceptance by others to feel appreciated. If family fails to provide acceptance, they would turn to other places that could provide this need (Erikson 1998). Friends could influence them to make a decision to use drugs and even relapse (Gouws et al. 2000). This is supported by findings in previous studies by Gouws et al. (2000) and McWhirter et al. (2004) that state friends as an important source in showing the main factor that brings about their inclination to relapse and affect full recovery (Taylor et al. 2006).

As stated by previous researchers, friends play an important role in increasing the rate of inclination to relapse after end of treatment and recovery. Friends seem to have the largest influence on former addicts to incline to relapse (Chen, Sheth, Elliott, \& Yeager 2004; Kandel 1996). For example, study done by Margolis, Kilpatrick \& Mooney, (2000) was done on pregnant women among ethnic minorities in North America. This study is based on factors influencing the inclination to relapse such as family and friends. Results found almost $57 \%$ of the female drug addicts stop taking drugs during their pregnancies. Results also found they begin to relapse due to friend influence. 
Results carried out by previous studies such as (Brandt \& Delport 2005; Fraser 2002; Goodwin 2000; Gordon 2003) also found friends could influence the inclination to relapse among former drug addicts. The friend factor discussed by previous researchers provided some understanding on the support of friends and the inclination to relapse among former drug addicts. According to Piko (2000), the friend and social environment factors are high predictors and individual involvement in drug use (O'Brien, Childress, Ehrman, \& Robbins 1998). Therefore, the risk to relapse becomes higher due to environment.

A study by Dishion et al. (2002) found that children are at a high risk of behaving negatively du to peer influence. According to Osgood \& Chambers (2000), most juvenile problems are caused by their choice of friends. They are more swayed by and more involved in friends and their activities that may include deviant ones. Findings show a positive relationship between friend support and the inclination to relapse among addicts. These factors increase the possibility of addicts to continue using drugs and affecting addiction recovery efforts (Taylor et al. 2006). Hence, mutually supportive friends is believed to help former addicts overcome challenges so they would not return to drugs.

According to Hall, Wasserman \& Havasay (1991), one of the factors leading to inclination to relapse is the social factor, such as societal acceptance as well as lack of social support. The presence of social ostracism and discrimination towards former addicts makes recovery and rehabilitation a difficult process. According to Corrigan, Kuwabara \& O'Shaughnessy (2009), the possibility to relapse increases within a six-month period after treatment because of lack of support from their environment.

Dobkin, Civita, Paraherakis, \& Gill (2002) in their study on 206 addicts found that the level of psychological problem and depression is higher among addicts with low societal support. A stressful lifestyle also increases the inclination to relapse within three to six months after the end of the treatment and rehabilitation process. This means the low level of social support after treatment ends not only increases stress in their lives, but also influences the addicts' psychological problems. In fact, psychological stress makes it difficult for them to socialise in the new environment, thus potentially increasing the inclination to relapse (Lang \& Belenko 2000).

Rosenfield (1997) states that social stigma is a negative influence on former addicts. Negative influence due to prejudice and discrimination by members of society complicates the former addict's recovery process. In addition, the public usually projects negative traits onto former addicts, such as them being untrustworthy, manipulative, lazy, and lead an idle life. Former addicts then use the negative stigma excuse to justify their actions to relapse due to discrimination by their environment.

Furthermore, findings also found that societal stigma and discrimination has a chronic social impact on the daily life of a former addict (Radcliffe \& Stevens 2008). This is proven through a study by O'Brien et al. (1998). On the difficulties faced by addicts to quit drugs. Findings show the main obstacle to change is related to the negative stigma by society, causing addicts to give up on their recovery process. The stigma causes addicts to feel ashamed to face society and take the initiative to isolate themselves from society, thus continuing with their usual activity. In fact, there are respondents who continue to use drugs and decide to stop the treatment process. This means there is a relationship between the negative stigma and recovery problems among addicts.

Westreich, Heitner \& Cooper (1997) in their study looked into societal support among former addicts and their findings found societal support is positively linked to the inclination to relapse. 66 former addicts were evaluated regarding social support after end of treatment and recovery. This study was done within 21 days after the end of the treatment process. 46 addicts were involved in the study, while the remaining 20 were not involved in the study as they could not provide full commitment until research ends. Findings show social support plays a role in treating former addicts facing societal pressure, and societal perception is an important factor preventing them from relapsing. 
A study by De Waele \& Van Hove (2005) found some respondents in their study reported acting based on stereotypes society has allotted them. Respondents admit they were unable to defend themselves when society threw insults at them. This made it difficult for addicts to reintegrate into society as they feel a large gap between themselves and members of society. The study also found most respondents state they have a strong desire to start a new life and among them are those who moved out of their hometowns to new areas. However, isolation and social stigma complicates their effort to assimilate into a new environment.

This situation reduces their confidence to remain drug-free, to be replaced by feelings of anxiety and insecurity due to unexpected environmental influences (Marlatt \& Gordon 1985). This unexpected environmental situation drives their inclination to relapse. Hawkins \& Catalano (1985) in their study found $6 \%$ of the repeat heroin addicts post-treatment and recovery do so after facing social pressure from society and environment.

\section{Research Method}

The population in this research consists of addicts that just finished their treatment and recovery at the CCRC within one to six months as most previous studies found their inclination to relapse to occur within one to six months after ending their treatment and recovery period. Cluster sampling is a sampling technique whereby all units within the cluster would be chosen. This means after cluster selection, all units within said cluster would be chosen as the study respondents. Four CCRCs were clustered according to zones, which are the Northern, Southern, Central, and Eastern Zones, representing the population in this study. This means only four CCRCs were selected as research cluster.

\section{Result \& Discussion}

Relationship between the inclination to relapse and the personal factors (coping and selfefficacy) and interpersonal factors (familial, friends, and societal support)

The results are in line with a number of previous studies such as Frydenberg (2002) and Kiser \& Black (2005) that shows a relationship between coping and inclination to relapse among former drug addicts. This is because the addict's attitude of lack of self-control causes them to be aggressive, and act out of control and expectation. The drug control exceeds their internal coping strength. According to Brown, Comtois, \& Linehan (2002) the relationship between emotional coping and the inclination to relapse is due to life stress that drive them to relapse. The stress faced leads to emotional incapability to cope leading to impulsive behaviour, thus harming the self.

\section{Table 1.}

Link between the personal factors (coping and self-efficacy), the interpersonal factors (familial, friend, and societal support) and the inclination to relapse among former drug addicts

\begin{tabular}{lcccccc}
\hline \multicolumn{1}{c}{ Variable } & $\mathrm{Y}$ & $\mathrm{X}_{1}$ & $\mathrm{X}_{2}$ & $\mathrm{X}_{3}$ & $\mathrm{X}_{4}$ & $\mathrm{X}_{5}$ \\
\hline $\mathrm{Y}$ (Inclination to Relapse) & 1 & & & & \\
& & & & & \\
$\mathrm{X}_{1}$ (Coping) & $.566^{* *}$ & 1 & & & \\
$\mathrm{X}_{2}$ (Self-efficacy) & $.652^{* *}$ & $.610^{* *}$ & 1 & & \\
$\mathrm{X}_{3}$ (Familial Support) & $.564^{* *}$ & $.530^{* *}$ & $.526^{* *}$ & 1 & \\
$\mathrm{X}_{4}$ (Friend Support) & $-.059^{* *}$ & $-.008^{* *}$ & $.030^{* *}$ & $-.149^{* *}$ & 1 & \\
$\mathrm{X}_{5}$ (Societal Support) & $.624^{* *}$ & $.513^{* *}$ & $.545^{* *}$ & $.577^{* *}$ & $-.045^{* *}$ & 1 \\
\hline
\end{tabular}


Meanwhile, addicts are likely to lack self-control skills. They feel abandoned by people around them and are inclined to spend more time with friends involved in the same activity. In addition, some young addicts do not enjoy full parental control. This situation allows for their mixing and being influenced by drug-using friends, thus increasing the risk of inclination to relapse.

The self-efficacy factor also shows a medium positive relationship. It is possible the existence of this relationship is because when respondents are in a troubling situation, their self-efficacy acts in response to the situation. Self-efficacy could decide the extent of one's ability to overcome stress and their endurance when faced with high-risk situations. This means self-efficacy could influence someone to act to chase expected goals. This study implies that addicts should prepare themselves with self-control abilities when faced with pressure to prevent their relapsing.

Furthermore, the interpersonal factors (familial, friend, and societal supports) are also seen as linked to the inclination to relapse, but the relationship of friend support with the inclination to relapse is negative. This means the existence of a medium relationship for social support is due to the respondents living within a collectivistic society. Of course, the social support aspect is emphasised upon. In addition, the Malay society trait of prioritising others also strengthens their social relationships. This result is unsurprising especially as Malays are known to be caring and supporting of each other, thus forming a strong social bond. The results also support the traditional view, especially in the Malay societal context, that still adheres to eastern values and manners. This situation causes the relationship between familial support and the inclination to relapse to be positive.

In fact, those with problems would find other sources to depend on support by family, friends, or others they think could help them overcome problems (Muuss 1996; Seiffge-Krenke 2000). However, when all required support is unachievable, they begin acting out of expectation when faced with stress. According to Walker (2002) and Wimbarti (2002) even though addicts that utilise problem-facing coping often have a dominating and aggressive attitude, they do not know how to manage problems faced due to the failure to control themselves and to plan to avoid continuous use of drugs. Possibly this factor increases the inclination to relapse.

This shows that family support is not the sole requirement of drug-involved children, but knowledge relating to prevention of relapsing should also be emphasised to help former addicts lead a new life. In fact, parents and family members should educate children involved in drug problems to not be fully dependent on family support to escape their addiction. In fact, family members should help them develop internal strength to face life challenges. This is done to aid the recovery process among former addicts and avoid the risk of inclination to relapse.

This findings supports a number of previous studies (Basson 2008; Fraser 2002; Goodwin 2000) that report social environments, including familial, friend, and societal support as important factors towards the inclination to relapse among drug addicts. Previous scholar also stress that he most effective method to prevent children's continued addiction is through high commitment by family members, which serve as the basic social unit, considered to have a positive influence on the social and behavioural development of children. This proves that family support allows addicts to face positive changes in their recovery process and also help them develop self-confidence.

The possible explanation to this situation is that children involved in drug problems need a supportive family environment to help them recover as normal individuals. The family context is said to facilitate the recovery process but the family could also potentially hinder rehabilitation. According to Hser et al. (2007) family could provide support to addicts to prevent addictive behaviour and responses that drive them to relapse. Furthermore, family support could offer the opportunity to addicts to learn the lifestyle of a normal person and become a positive social source. This then helps former addicts to fill recreational time with rewarding activities and prevent them from returning to drug habits.

As explained before, study respondents reported receiving high levels of support from the family. 
This means parents and family members are sources for dependence for these addicts. According to Fatimah (1983), parents are among individuals that could fulfil the needs and requirements of children such as moral and emotional support, shelter, love, and so on. Addicts need acceptance and support from individuals close to them. If the family fails to provide support, they would turn to other forms of support to fulfil their requirements. Therefore, the parents' role as their children's social behaviour educators allows them to recognise their strengths and flaws. With that in mind, the researcher is of the opinion that the Malay societal trait of prioritising family means children involved in drug problems have high level of family support in this study.

The results are unsurprising as Malay society is known for their caring and mutually supporting traits, leading children to say they received high level of family support. This clearly describes Malay societal lifestyle still maintains collectivistic societal patterns. This is acknowledged by Taib \& Khairi (2000) in their study that family support is required to ensure the success of the recovery process and family indifference and isolation of former addicts would hinder the recovery process, leading them to relapse. Family support could help former addicts from relapsing into their old habits. They also concluded that the high level of moral and emotional support indirectly increases the addicts' selfconfidence and reduces the risk towards relapsing.

This situation describes the addicts as not only needing family support to be free from drug problems, but they also need good family environment for positive self-development. This is because family internal problems would force them to lose self-control thus leading them to seek an easy way out by returning to drug use. This situation also exposes them to relapsing by following their emotions as the implication of the conflict and pressures they face. Therefore, it should be emphasised that the family is the social unit capable of helping addicts towards full recovery. Brandt \& Delport (2005) also found that addicts with supportive and close family environment would not relapse compared to addicts without family support. The close relationship with family members maintains the addicts' recovery process post-treatment, while loose familial bonds complicates the recovery process for addicts.

\section{Conclusion}

In conclusion, in this study, the personable variable of coping is identified as the main predictor that leads to the inclination to relapse, followed by the familial and societal supports variables. The three factors have been identified as having a positive and strong significant link with the inclination to relapse. In fact, findings also clearly report that social support could have an indirect effect on the inclination to relapse. The lack of a social support system to help former addicts, especially those who just finished their treatment and recovery process is a challenging issue in the context of treatment. Realising the importance of social support in the effort to help former addicts, the work to establish a steady support system via the community should be given attention. Societal involvement, which includes neighbours, village headmen, neighbourhood associations, mosque committee members, and peer counsellors are needed to cooperate with the authorities to increase efforts to help overcome this seemingly never-ending problem. Society should also be more prepared to participate in efforts to guide former addicts that just ended their treatment and recovery process so they would no longer be trapped in drug problems.

\section{References}

Akers RL (1998) Social Learning and Social Structure: A General Theory of Crime and Deviance. Northeastern University Press.

Akers RL (1998) Deviant Behavior: A Social Learning Approach, $2^{\text {nd }}$ ed. Belmont, CA: Wadsworth Press.

Annis HM (1982) Inventory of Drinking Situations. Toronto, Canada: Addiction Research Foundation. Basson N (2008) The influence of psychosocial factors on the subjective well being of adolescents. 
Dissertation submitted in accordance with requirements for the degree of Magister Societatis Scientiae (Psychology) in the Faculty of Humanities Department of Psychology. University of the Free State Bloemfontein.

Brandt CJ \& Delport CSL (2005) Theories of adolescent substance use and abuse. Professional Journal for Social Work, 41 (2):163-175.

Breese GR (2005) Stress enhancement of craving during sobriety and the risk of relapse. Alcoholism: Clinical and Experimental Research, 29:185-195.

Brooks CS \& Rice KF (2007) Families in Recovery: Coming Full Circle. Baltimore: Paul H. Brookes Publishing Co.

Chen K, Sheth AJ, Elliott DK, \& Yeager A (2004) Prevalence and correlates of past-year substance use, abuse, and dependents in a suburban community sample of high-school students. Addictive Behaviors, 29:413-423.

Compas BE (1987) Coping with stress during childhood and adolescence. Psychological Buletin. 101 (3):393-403.

Conger RD \& Rueter MA(1996) Siblings, Parents, and Peers: A Longitudinal Study of Social Influences in Adolescent Risk for Alcohol Use and Abuse. In: GH Brody (ed). Sibling Relationships: Their Causes and Consequences. Stamford, CT: Ablex.

Conger RD \& Simons SL (1997) Life-Course Contingencies in the Development of Adolescent Antisocial Behavior: A Matching Law Approach. In: TP Thornberry (ed). Development Theories of Crime and Delinquency: Advances in Criminological Theory. New Brunswick, N.J.Transaction.

Cornelius JR, Maisto SA, \& Pollock NK (2003) Rapid relapse generally follows treatment for substance use disorders among adolescents. Addictive Behaviors, 28 (2):381-386.

Corrigan PW, Kuwabara SA, \& O'Shaughnessy J (2009) The public stigma of mental illness and drug addiction:Findings from a stratified random sample. Journal of Social Work, 9 (2):139-147.

Cutrona CE \& Russell DW (1987) The provisions of social relationships and adaptation to stress. Advances in Personal Relationships, 1:37-67.

De Waele I \& Van Hove G (2005) Modern times: An ethnographic study on the quality of life of people with a high support need in a Flemish residential facility. Disability and Society, 20 (6):625639.

Dimeff LA \& Marlatt GA (1998) Preventing relapse and maintaining change in addictive behaviors. Clinical Psychology: Science \& Practice 5 (4):513-525.

Dishion TJ \& Owen LD (2002) A longitudinal analysis of friendships and substance use: Bidirectional influence from adolescence to adulthood. Developmental Psychology, 38:480-491.

Dishion TJ, Poulin F, \& Burraston B (2001) Peer Group Dynamics Associated with Iatrogenic Effects in Group Interventions with High-Risk Young Adolescents. In: DW Nangle \& CA Erdley (eds). The Role of Friendship in Psychological Adjustment. New Directions For Child And Adolescent Development, No. 91:79-92. San Francisco: Jossey-Bass.

Dobkin P, De Civita M, Paraherakis A, \& Gill K (2002) The role of functional social support in treatment retention and outcomes among outpatient adult substance abusers. Addiction, 97:347-356.

Dodge R, Sindelar J, \& Sinha R (2005) The role of depressive symptoms in predicting drug abstinence in outpatient substance abuse treatment. Journal of Substance Abuse Treatment, 28:189-196.

Focus Adolescent Service (2006) Teenagers and drugs Retrieved 3/4, 2006, from http://www.focusas. com/Substanceqabuse.html.

Focus Adolescent Service (2008) Self-help and support group Retrieved 3/4, 2008, from http://www. focusas.com/SelfHelp.html.

Folkman S \& Lazarus RS (1984) Coping and adaptation. Dlm. Gentry, W. (pnyt.), Handbook of Behavioral Medicine. New York: Basic Books Inc.

Fraser MW (2002) Risk and Resilience in Childhood. An ecological perspective. Washington: NASW. Frydenberg E (2002) Adolescent Well-Being. Building Young People's Resources. In: Frydenberg E \& Lewis R (eds), Beyond coping. Meeting goals, visions.

Goodwin DW (2000) Alcoholism: The Facts (3rd ed.). Oxford: Oxford University Press.

Gouws E, Kruger N, \& Burger S (2000) The adolescent (2th ed). Sandown: Heineman publishers.

Greenfield S, Hufford M, Vagge L, Muenz L, Costello M, \& Weiss R (2000) The relationship of self- 
efficacy expectancies to relapse among alcohol dependent men and women: A prospective study. Journal of Studies on Alcohol, 61:345-351.

Greenfield SF, Brooks AJ, Gordon SM, Green CA, Krop F, \& McHugh RK (2007) Substance abuse treatment entry, retention, and outcome in women: A review of the literature. Drug and Alcohol Dependence, 86 (1):1-21.

Gulliver SB, Hughes JR, Soloman LJ, \& Dey AN (1995) An investigation of self-efficacy, partner support and daily stresses as predictors of relapse to smoking in self quitters. Addiction, 90:767-772.

Haegerich T \& Tolan PH (2009) Core Competencies and Prevention of Adolescent Substance Use. NG Guerra \& C Bradshaw (eds). Youth At Risk: Core Competencies to Prevent Problem Behaviors and Promote Positive Youth Development. New Directions in Child Development. In: R Larson \& LA Jensen (ed). New York: Josey-Bass.

Hall SM, Havassy BE, \& Wassermann DA (1990) Commitment to abstinence and acute stress in relapse to alcohol, opiates and nicotine. Journal Counseling Clinical Psychology, 58:175-181.

Hall SM, Wasserman DA, \& Havasay BL (1991) Relapse Prevention. In: RW Pickens, CG Leukefeld, \& SR Schuster. Improving Drug Abuse Treatment. Rockeville, MD: NIDA.

Hawkins JD \& Catalano RF (1985) Aftercare in drug abuse treatment. The International Journal of the Addictions, 20 (689):917-945.

Hser Y, Evans E, Huang D, \& Anglin DM (2004) Relationship between drug treatment services, retention, and outcomes. Psychiatric Services,55:767-774.

Hser Y, Longshore D, \& Anglin M (2007) The life course perspective on drug use: a conceptual framework for understanding drug use trajectories. Evaluation Review, 31 (6):515-547.

Kandel DB (1996) The parental and peer contexts of adolescent deviance: An algebra of interpersonal influences. Journal of Drug Issues, 26:289-315.

Kiser LJ \& Black MM (2005) Family processes in the midst of urban poverty: What does the trauma literature, tell us? Department of Psychiatry, School of Medicine. Baltimore United State of America: University of Maryland.

Klingemann H (1991) The motivation for change from problem alcohol and heroin use. British Journal of Addiction, 86:727-744.

Klingemann H (1994) Environmental Influences Which Promote or Impede Change in Substance Behaviour. In: Edwards G \& Lander M. (eds). Addiction: Processes of Change. Oxford: Oxford University Press.

Lang MA \& Belenko S (2000) Predicting retention in a residential drug treatment alternative to prison program. Journal of Substance Abuse Treatment, 19:145-160.

Luoma JB, Twohig MP, Waltz T, Hayes SC, Roget N, Padilla M, \& Fisher G (2007) An investigation of stigma in individuals receiving treatment for substance abuse. Addictive Behaviors, 32:13311346.

Macleod J, Hickman M, \& Smith G (2005) Reporting bias and self-reported drug use. Addiction, 100:560-563.

Margolis R, Kilpatrick A, \& Mooney B (2000) A retrospective look at long-term adolescent recover: Clinicians talk to researchers. Journal of Psychoactive Drugs, 32:117-125.

Marlatt \& Gordon JR (1985) Relapse Prevention: Maintenance Strategies in the Treatment of Addictive Behaviors. New York: Guilford Press.

Marlatt GA (1985) Relapse Prevention: Theoretical Rationale and Overview of the Model. In GA Marlatt \& JR Gordon (eds). Relapse Prevention: Maintenance Strategies in the Treatment of Addictive Behaviors, 3-70.

Martino SC, Ellickson PL, \& McCaffrey DF (2009) Multiple trajectories of peer and parental influence and their association with the development of adolescent heavy drinking. Addictive Behaviors, 34:693-700.

McIntosh J \& McKeganey N (2000) Addicts' narratives of recovery from drug use: constructing a nonaddict identity. Social Science \& Medicine, 50:1501-1510.

McWhirter EH, Rasheed S, \& Crothers M (2000) The effects of high school career education on socialcognitive variables. Journal of Counseling Psychology, 47:330-341.

Minervini I, Palandri S, Bianch S, Bastiani L, \& Paffi D (2011) Desire and coping self-efficacy as 
craving measures in addiction: The self-efficacy and desire scale (SAD). The Open Behavioral Science Journal, 11 (5):1-7.

Moon DG, Jackson KM, \& Hecht ML (2000). Family risk factors, substance use, and the drug resistance process in adolescence. Journal of Drug Education, 30:373-398.

Muuss R (1996) Theories of Adolescence, 6th Edition. New York: McGraw-Hill Publishers.

Nevide JS, Rathus SA, \& Greene B (2011) Abnormal Psychology in a changing world. United State of America: Pearson.

O'Brien CP, Childress AR, Ehrman RN, \& Robbins SJ (1998) Conditioning factors in drug abuse: can they explain compulsion? Journal Psychopharmacol,12:15-22.

Perdani R (2012) The Experience of Family Support by People in the Recovery of Drug Addiction. Faculty of Leadership and Management, Universiti Sains Islam Malaysia, Negeri Sembilan, Malaysia.

Piko (2000) Perceived social support from parents and peers: Which is the stronger predictor of adolescent substance use? Substance use Misused, 35 (4):617-30.

Radcliffe P \& Stevens A (2008) Are drug treatment services only for 'thieving junkie scumbags?' Drug users and the management of stigmatised identities. Social Science and Medicine, 67:10651073.

Ramo DE \& Brown SA (2008) Classes of substance abuse relapse situations: A comparison of adolescents and adults. Psychology of Addictive Behaviors, 22:372-379.

Room R (2005) Stigma, social inequality and alcohol and drug use. Drug and Alcohol Review, 24 (2):143-155.

Rosenfield S (1997) Labelling mental illness: The effects of received services and perceived stigma on life satisfaction. American Sociological Review, 62:660-672.

Russell D \& Cutrona CE (1987) The Social Provision Scale: A Multidimensional Measure of Perceived Social Support. In WH Jones \& D Perlman (eds). Advances in personal relationships. Greenwich, Conn: JAI Press.

Scott CK, Dennis ML, \& Foss MA (2005) Utilizing recovery management checkups to shorten the cycle of relapse, treatment reentry, and recovery. Drug and Alcohol Dependence, 78:325-338.

Scott CK, Foss MA, \& Dennis ML (2005) Pathways in the relapse treatment recovery cycle over 3 years. Journal Substance Abuse Treat, 28:63-72.

Seiffge-Krenke I (2000) Causal links between stressful events, coping style, and adolescent symptomatology. Journal Adolescence, 23:675-691.

Simons RL, Christine J, Rand DC, \& Glen H (1998) A test of latent trait versus life course perspectives on the stability of adolescent antisocial behavior. Criminology, 36 (2):217-243.

Sinha R \& Li CS (2007) Imaging stress and cue induced drug and alcohol craving: association with relapse and clinical implications. Drug and Alcohol Review, 26:25-31.

Sinha R (2001) How does stress increase risk of drug abuse and relapse? Psychopharmacology, 158:343-359.

Stimson GV, \& Oppenheimer E, (1982) Heroin Addiction: Treatment and Control in Britain. London: Tavistock.

Taylor BJ, Graham JW, Cumsille P, \& Hansen WB (2000) Modeling prevention program effects on growth in substance use: Analysis of five years of data from the Adolescent Alcohol Prevention Trial. Prevention Science, 1:183-197.

Taylor J, Lioyd DA, \& Warheit GJ (2006) Self-derogation, peer factors, and drug dependence among a multiethnic sample of young adults. Journal of Child and Adolescent Substance Abuse, 15(2):39-51.

Van Der Westhuizen MA (2007) Relapsing after treatment: Exploring the experiences of chemically addicted adolescents. Unpublished MA dissertation, Department of Social work, University of South Africa.

Verdejo GA (2007) Negative emotiondriven impulsivity predicts substance dependence problems. Drug Alcohol Dependance, 91:213-219.

Wimbarti S (2002) Children's aggression in Indonesia: The effect of culture, familial factors, peers, television violence viewing and temperament. University Southern California. 